Hydrology and Earth System Sciences, 6(3), 325-337 (2002) C $\quad$ EGS

\title{
Nitrous oxide emission from a range of land uses across Europe
}

\author{
S.E.Machefert ${ }^{1}$, N.B.Dise ${ }^{1}$, K.W.T.Goulding ${ }^{2}$ and P.G.Whitehead ${ }^{3}$ \\ ${ }^{1}$ Department of Earth Sciences, The Open University, Milton Keynes, MK7 6AA, UK \\ ${ }^{2}$ Agriculture and Environment Division, IACR Rothamsted, Harpenden, AL5 2JQ, UK \\ ${ }^{3}$ Aquatic Environments Research Centre, Department of Geography, University of Reading, Reading, RG6 6AB, UK
}

Email for corresponding author: s.e.machefert@open.ac.uk

\begin{abstract}
The results of a literature study examining quantitative estimates of $\mathrm{N}_{2} \mathrm{O}$ emission rates are presented for a range of land-uses across Europe. The analysis shows that the highest $\mathrm{N}_{2} \mathrm{O}$ emission rates are for agricultural lands compared to forests and grasslands. The main factors regulating these rates are available mineral nitrogen, soil temperature, soil water content and the available labile organic compounds. These controls operate across different time-scales, all must exceed a certain threshold for $\mathrm{N}_{2} \mathrm{O}$ emission to occur. The results support the need for an emission factor function of land-use and climate within models describing nitrogen dynamics in catchments. This would allow the assessment of the net $\mathrm{N}_{2} \mathrm{O}$ emission within catchments in terms of current levels and potential changes associated with climate variability, climate change and land use change.
\end{abstract}

Keywords: nitrous oxide, soil water content, inorganic N, soil temperature, ecosystems, land-use management, soil type

\section{Introduction}

Soils are the most important source of atmospheric nitrous oxide $\left(\mathrm{N}_{2} \mathrm{O}\right)$, contributing an estimated $70 \%$ to the total globally emitted $\mathrm{N}_{2} \mathrm{O}$ (Bouwman, 1990). To the extent that soils are managed, especially if they receive nitrogen fertilisers, or are impacted upon by atmospheric $\mathrm{N}$ deposition, they are also an anthropogenic source of $\mathrm{N}_{2} \mathrm{O}$. Other sources of $\mathrm{N}_{2} \mathrm{O}$ are the oceans, biomass burning and emissions from industrial processes and automobiles (Bange, 2000). Nitrous oxide is of great interest from an environmental point of view because it is an important greenhouse gas present in the lower atmosphere (the troposphere) at about $0.00003 \%$. Although $\mathrm{N}_{2} \mathrm{O}$ constitutes only $6 \%$ of the anthropogenic greenhouse effect (Bouwman, 1998), it has a radiative forcing 180 times greater than carbon dioxide (Lashof and Ahuja, 1990; Mogge et al., 1998). It also contributes to the depletion of stratospheric ozone. Over the last 25 years the concentration of $\mathrm{N}_{2} \mathrm{O}$ in the atmosphere has risen by about $0.25 \%$ per year (Flessa et al., 1995). In comparison, the atmospheric concentration of carbon dioxide has been increasing at about $0.3 \%$ per year since the 1960s and that of methane, another greenhouse gas, by $1 \%$ per year.
$\mathrm{N}_{2} \mathrm{O}$ is both emitted and absorbed by soils, but the net flux is almost always emission. Due to seasonal and spatial variation, $\mathrm{N}_{2} \mathrm{O}$ emissions are difficult to quantify (Smith et al., 1994) and the estimation of annual emissions from a small number of observations may lead to considerable errors. This emphasises the need for long-term studies to overcome the problem.

A recent review by Wrage et al. (2001) brought together information on $\mathrm{N}_{2} \mathrm{O}$ fluxes, but only for nitrifier denitrification. This paper provides a more comprehensive review of $\mathrm{N}_{2} \mathrm{O}$ fluxes for a range of land-uses across Europe from all sources. This work aims to identify the main factors influencing these emissions and to compare $\mathrm{N}_{2} \mathrm{O}$ emission estimates for different ecosystems (forests, grasslands and agricultural land).

\section{Processes}

Two mechanisms are mainly responsible for $\mathrm{N}_{2} \mathrm{O}$ emissions from soils: microbial nitrification and denitrification (Table 1). A third, not well known process has recently been studied by Wrage et al. (2001): nitrifier denitrification. This process 
Table 1. Factors favouring Nitrification and Denitrification processes

\begin{tabular}{|c|c|c|}
\hline & Nitrification & Denitrification \\
\hline $\begin{array}{l}\text { Substrate } \\
\text { availability }\end{array}$ & $\begin{array}{l}\mathrm{NH}_{4}^{+} \text {, urea, } \\
\text { amino acids }\end{array}$ & $\mathrm{NO}_{3}^{-}$ \\
\hline $\begin{array}{l}\mathrm{O}_{2} \\
\text { concentration }\end{array}$ & high & low \\
\hline $\begin{array}{l}\text { reduced } \\
\text { carbon }\end{array}$ & No effect & $\begin{array}{l}\text { high } \\
\text { (energy source) }\end{array}$ \\
\hline $\begin{array}{l}\text { moisture } \\
\text { (water filled } \\
\text { pore space) }\end{array}$ & $\begin{array}{l}\text { intermediate } \\
30-70 \% \text { WFPS }\end{array}$ & $\begin{array}{l}\text { high } \\
55-100 \% \text { WFPS }\end{array}$ \\
\hline $\begin{array}{l}\text { soil } \\
\text { temperature }\end{array}$ & $\begin{array}{l}\text { high } \\
\text { (within range) }\end{array}$ & $\begin{array}{l}\text { high } \\
\text { (within range) }\end{array}$ \\
\hline $\mathrm{pH}$ & $>5$ & Low $(<5)$ \\
\hline
\end{tabular}

is carried out by autotrophic nitrifiers that oxidize ammonia $\left(\mathrm{NH}_{3}\right)$ to nitrite $\left(\mathrm{NO}_{2}^{-}\right)$and then reduce $\mathrm{NO}_{2}^{-}$to nitric oxide (NO), nitrous oxide $\left(\mathrm{N}_{2} \mathrm{O}\right)$ and molecular nitrogen $\left(\mathrm{N}_{2}\right)$. Nitrifier denitrification can lead to substantial $\mathrm{N}_{2} \mathrm{O}$ emissions especially when low oxygen conditions are coupled with low organic carbon contents of soils and low $\mathrm{pH}$. The maximum amount of $\mathrm{N}_{2} \mathrm{O}$ lost via nitrifier denitrification in soils represents about $30 \%$ of the total $\mathrm{N}_{2} \mathrm{O}$ production (Webster and Hopkins, 1996).

Nitrification consists of the oxidation of ammonium $\left(\mathrm{NH}_{4}^{+}\right)$to nitrite $\left(\mathrm{NO}_{2}^{-}\right)$and then nitrate $\left(\mathrm{NO}_{3}^{-}\right)$. It is an aerobic process carried out by a few genera of autotrophic bacteria able to use the energy generated from these processes. The best studied are the obligate chemoautotrophs, Nitrosomonas and Nitrobacter species (Robertson and Kuenen, 1991). At sub-optimal oxygen concentrations oxidation into $\mathrm{NO}_{3}^{-}$is incomplete and some of the $\mathrm{NH}_{4}^{+}$is channelled into the production of $\mathrm{NO}$ and $\mathrm{N}_{2} \mathrm{O}$ (Poth and Focht, 1985). Bremner and Blackmer (1981) report that $\mathrm{N}_{2} \mathrm{O}$ production is higher with added nitrifiable nitrogen (e.g. urea or ammonium containing fertiliser). Nitrification occurs most rapidly when soil $\mathrm{pH}$ is between 5.5 and 6.5 (Kasica, 1997). For instance, nitrification rates from pasture soils have been found to be higher in the zone of the soil with a $\mathrm{pH}$ value of 5.7 than in a deeper soil layer with a $\mathrm{pH}$ value of 4.7 (Black et al., 1998). In the field, nitrification can also be controlled by the moisture content and temperature of the soil.
Denitrification is the anaerobic process by which nitrate $\left(\mathrm{NO}_{3}^{-}\right)$and nitrite $\left(\mathrm{NO}_{2}^{-}\right)$are reduced to give nitric oxide (NO), nitrous oxide $\left(\mathrm{N}_{2} \mathrm{O}\right)$ and dinitrogen $\left(\mathrm{N}_{2}\right)$. It requires a ready supply of reduced carbon for energy and $\mathrm{NO}_{3}{ }^{-}$as a substrate. A wide range of micro-organisms can denitrify. They are facultative anaerobes and switch to $\mathrm{NO}_{3}^{-}$as a terminal electron acceptor when oxygen is unavailable. Important environmental controls for denitrification include temperature, soil moisture and $\mathrm{pH}$. Denitrification will have different products depending on the level of soil moisture, with NO favoured by lower soil moisture grading into $\mathrm{N}_{2}$ favoured at the highest soil moisture. However, it is still unclear exactly what level of soil moisture will lead to primarily $\mathrm{NO}, \mathrm{N}_{2} \mathrm{O}$ or $\mathrm{N}_{2}$.

The extent to which these two processes, nitrification and denitrification, contribute to $\mathrm{N}_{2} \mathrm{O}$ emission will vary with climate, soil conditions and soil management. Generally, high rainfall, poor drainage, fine soil texture and high organic carbon content promote denitrification whereas low rainfall, good drainage and aeration and coarse texture promote nitrification (Groffman, 1991). However, due to the complex interactions of the factors influencing the processes, it is difficult in most soils to determine which process prevails and what proportion of the nitrogen released is $\mathrm{N}_{2} \mathrm{O}$. The processes of denitrification and nitrification can also co-occur at the same time in a single site due to micro-scale soil heterogeneity and the balance between the two processes can switch very rapidly.

\section{Material description and methods}

The analysis was made by compiling data from reviews and site-specific field experiments on $\mathrm{N}_{2} \mathrm{O}$ flux controls for a variety of European ecosystems (Appendix 1). The 33 individual experiments from 13 references are from grasslands (fertilised or non-fertilised), forests (subjected to variable amounts of atmospheric $\mathrm{N}$ deposition) and agricultural sites (different crop types) across Europe. Only studies with at least 1 year's data are included. The determination of $\mathrm{N}_{2} \mathrm{O}$ emission rates for all of the 13 references considered was made using the closed chamber method (Hutchinson and Mosier, 1981) and gas samples were then analysed by gas chromatography. The standard soil- and weather-dependent parameters were measured in most cases. These include monitoring of precipitation, air temperatures, soil temperatures at different depths (digital thermometer), water-table levels and $\mathrm{pH}$ of soil in water. Soil water content was determined and results were given either as volumetric water content, gravimetric water content $(\mathrm{wt} / \mathrm{wt})$ or as water filled pore space. Soil analysis for nitrate and ammonium concentrations $\left(\mathrm{KCl}\right.$ or $\mathrm{KAl}\left(\mathrm{SO}_{4}\right)_{2}$, Papen 
and Butterbach-Bahl, 1999 , extractions) were also performed. The water-soluble organic carbon compounds were determined in the method described in Burford and Bremner (1975) and the soil organic matter as Loss-On Ignition method.

\section{Results}

Brumme et al. (1999) report a study of eleven forest ecosystems in Germany comprising mainly alder, beech and spruce (Table 2). Element budgets and soil characteristics were measured in these forests and showed distinct differences between sites, including $\mathrm{pH}$ ranging from 3.6 to 5.6. Nitrogen deposition ranged from 20 to $41 \mathrm{~kg} \mathrm{~N}$ $\mathrm{ha}^{-1} \mathrm{yr}^{-1}$. In these ecosystems, the soil surfaces were more or less covered by herbaceous vegetation. Nitrous oxide emissions were measured weekly or biweekly over one year with closed chambers.

Brumme et al. (1999) distinguished three types of emission patterns determined by the differences in temporal variation: (a) 'seasonal' emission pattern, (b) 'event-based' emission pattern and (c) 'background' emission pattern. The 'background' pattern is characterised by low annual fluxes. They found that most sites show background emission patterns, with low emissions during the whole year and low annual site means ranging from 0.17 to $0.80 \mathrm{~kg} \mathrm{~N}_{2} \mathrm{O}-\mathrm{N}$ $\mathrm{ha}^{-1} \mathrm{yr}^{-1}$ (Table 2). Similar and relatively constant $\mathrm{N}_{2} \mathrm{O}$ emissions were found in one forest in Finland (Martikainen et al., 1994), three forests in the UK (Skiba et al., 1996), one other forest in Germany (Mogge et al., 1998) and two forests in Denmark (Ambus and Christensen, 1995), with annual emissions ranging from 0.12 to $0.8 \mathrm{~kg} \mathrm{~N}_{2} \mathrm{O}-\mathrm{N} \mathrm{ha}^{-1}$ $\mathrm{yr}^{-1}$ (Appendix 1). Only two of the sites studied by Brumme et al. (1999) appeared to display 'seasonal' patterns. Such sites are characterised by a period of elevated rates in summer. These two sites had much higher annual fluxes: 3.0 and $7.3 \mathrm{~kg} \mathrm{~N}_{2} \mathrm{O}-\mathrm{N} \mathrm{ha}{ }^{-1} \mathrm{yr}^{-1}$ (Table 2). Some of the forested sites listed in Appendix 1 show similar fluxes. The 'event' emission pattern is characterised by short peaks of $\mathrm{N}_{2} \mathrm{O}$ emission during or following periods such as frost or thaw. Brumme et al. (1999) observed this type of emission at a drained site in Germany, with $\mathrm{N}_{2} \mathrm{O}$ flux changing from $100 \mu \mathrm{g} \mathrm{N}_{2} \mathrm{O}-\mathrm{N} \mathrm{m}^{-2} \mathrm{~h}^{-1}$ to about $500 \mu \mathrm{g} \mathrm{N}_{2} \mathrm{O}-\mathrm{N} \mathrm{m}^{-2} \mathrm{~h}^{-1}$ with the onset of the spring thaw in 1996.

The results from the 33 sites together with the data from Brumme et al. (1999) are presented in Fig. 1. These data indicate a gradient of $\mathrm{N}_{2} \mathrm{O}$ emissions with low fluxes for forests and grasslands, and higher emissions from agricultural fields. However, five forested sites show $\mathrm{N}_{2} \mathrm{O}$ emissions within the same range obtained for the arable agricultural sites; these are in Höglwald (two sites), Solling, Schelswig-Holstein and Bornhöved in Germany. Annual emissions were $2.18 \mathrm{~kg} \mathrm{~N}_{2} \mathrm{O}-\mathrm{N} \mathrm{ha}^{-1} \mathrm{yr}^{-1}, 3 \mathrm{~kg} \mathrm{~N} \mathrm{O}_{2} \mathrm{O}-\mathrm{N} \mathrm{ha}^{-1}$ $\mathrm{yr}^{-1}, 3.81 \mathrm{~kg} \mathrm{~N}_{2} \mathrm{O}-\mathrm{N} \mathrm{ha}^{-1} \mathrm{yr}^{-1}, 4.9 \mathrm{~kg} \mathrm{~N}_{2} \mathrm{O}-\mathrm{N} \mathrm{ha}^{-1} \mathrm{yr}^{-1}$ and 7.3

Table 2. Annual losses of nitrous oxide and some site characteristics

\begin{tabular}{|c|c|c|c|c|c|c|}
\hline Site location & Vegetation & $\begin{array}{l}\mathrm{N}_{2} \mathrm{O} \\
\mathrm{kg} \mathrm{N}_{2} \mathrm{O}-\mathrm{Nha^{-1 }} y r^{-1}\end{array}$ & $\begin{array}{l}\text { Soil Bulk density } \\
(0-5 \mathrm{~cm}) \\
\mathrm{g} \mathrm{cm}^{-3}\end{array}$ & $\begin{array}{l}\text { Precipitation } \\
m m y r^{-1}\end{array}$ & $\begin{array}{l}N^{c} \text { deposition } \\
K g N h a^{-1} y r^{-1}\end{array}$ & $\begin{array}{l}\text { Type of } \\
\text { flux }\end{array}$ \\
\hline
\end{tabular}

$\begin{array}{lllllll}\text { Bornhoved (d) } & \text { alder } & 7.3 & 0.48 & 697 & 33 & \mathrm{~s} \\ \text { Solling } & \text { beech } & 3.0 & 1.01 & 1090 & 35 & \mathrm{~s} \\ \text { Harz } & \text { spruce } & 1.3 & 1.2 & 1239 & 20 & \mathrm{~b} \\ \text { Bornhoved } & \text { alder } & 0.80 & - & 697 & 33 & \mathrm{e} \\ \text { Lappwald } & \text { spruce } & 0.56 & 1.2 & 650 & - & \mathrm{b} \\ \text { Zierenberg } & \text { beech } & 0.41 & 0.75 & 700 & 21 & \mathrm{~b} \\ \text { Harste } & \text { beech } & 0.36 & 1.17 & 750 & 26 & \mathrm{~b} \\ \text { Lappwald } & \text { beech/oak } & 0.29 & 0.85 & 650 & - & \mathrm{b} \\ \text { Solling } & \text { spruce } & 0.26 & 0.91 & 1090 & 41 & \mathrm{~b} \\ \text { Spanbeck } & \text { spruce } & 0.21 & 1.01 & 650 & 31 & \mathrm{~b} \\ \text { Gottinger Wald } & \text { beech } & 0.17 & 0.79 & 680 & 28 & \mathrm{~b}\end{array}$

Data from Brumme et al. (1999)

(d) - drained

${ }^{\text {c }}$ Throughfall of $\mathrm{NH}_{4}^{+}+\mathrm{NO}_{3}^{-}+\mathrm{N}_{\text {org }}$

$\mathrm{s}=$ 'seasonal'; $\mathrm{b}=$ 'background'; $\mathrm{e}=$ 'event-based' 


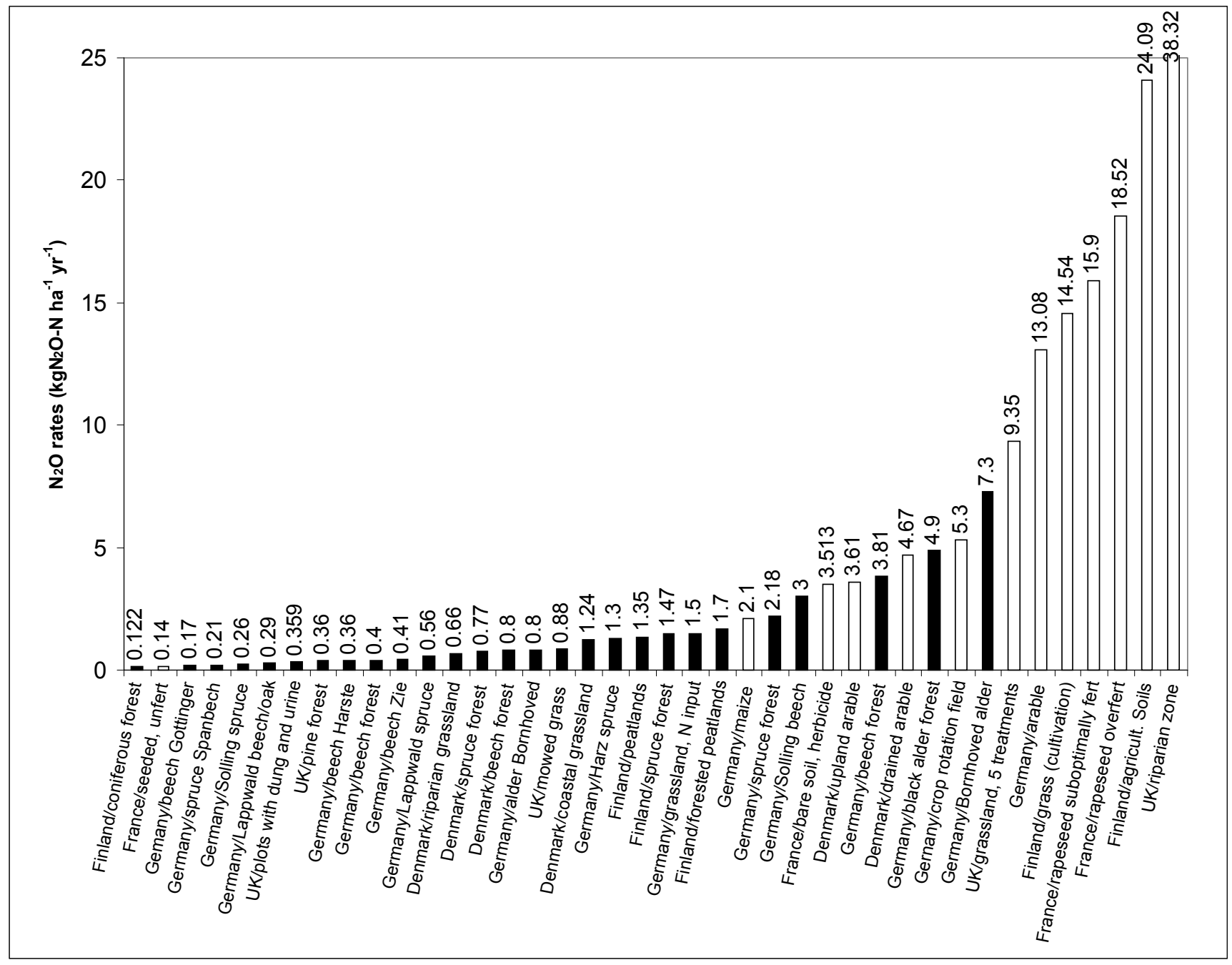

Fig. 1 Nitrous oxide emission rates for different European ecosystems - Black bars represent the forested and grassland ecosystems. White bars represent the agricultural ecosystems

$\mathrm{kg} \mathrm{N}_{2} \mathrm{O}-\mathrm{N} \mathrm{ha} \mathrm{yr}^{-1}$ respectively. Germany is among the European countries receiving the highest atmospheric $\mathrm{N}$ deposition as oxidised or reduced nitrogen. The mean annual precipitation for these regions is about $850 \mathrm{~mm}$. The soils are acidic and mostly organic.

\section{Discussion}

Nitrous oxide emissions from soils have been widely studied in the past decades and it is generally agreed that the main processes responsible for emissions, namely nitrification and denitrification, are not controlled by only one parameter but by several interacting parameters making predictions very difficult.

\section{SOIL MOISTURE, BULK DENSITY, RAINFALL}

Hydrological factors seem to exert the strongest controls on annual $\mathrm{N}_{2} \mathrm{O}$ emissions for most of the sites studied by Brumme et al.(1999). These factors affect nitrification and denitrification in different ways. Denitrification will be favoured by high moisture contents whereas nitrification will occur in drier soils. For instance, it has been observed (Davidson, 1991) that nitrification is the dominant source of $\mathrm{N}_{2} \mathrm{O}$ when water filled pore space (WFPS, calculated using gravimetric water content) is less than $60 \%$ and that denitrification is the predominant source when WFPS is greater than $60 \%$. By comparison, Fig. 2 shows the relationship between annual $\mathrm{N}_{2} \mathrm{O}$ emissions and bulk density (data from Brumme et al., 1999). There is no strong correlation. In addition, the data obtained by Brumme et al. 

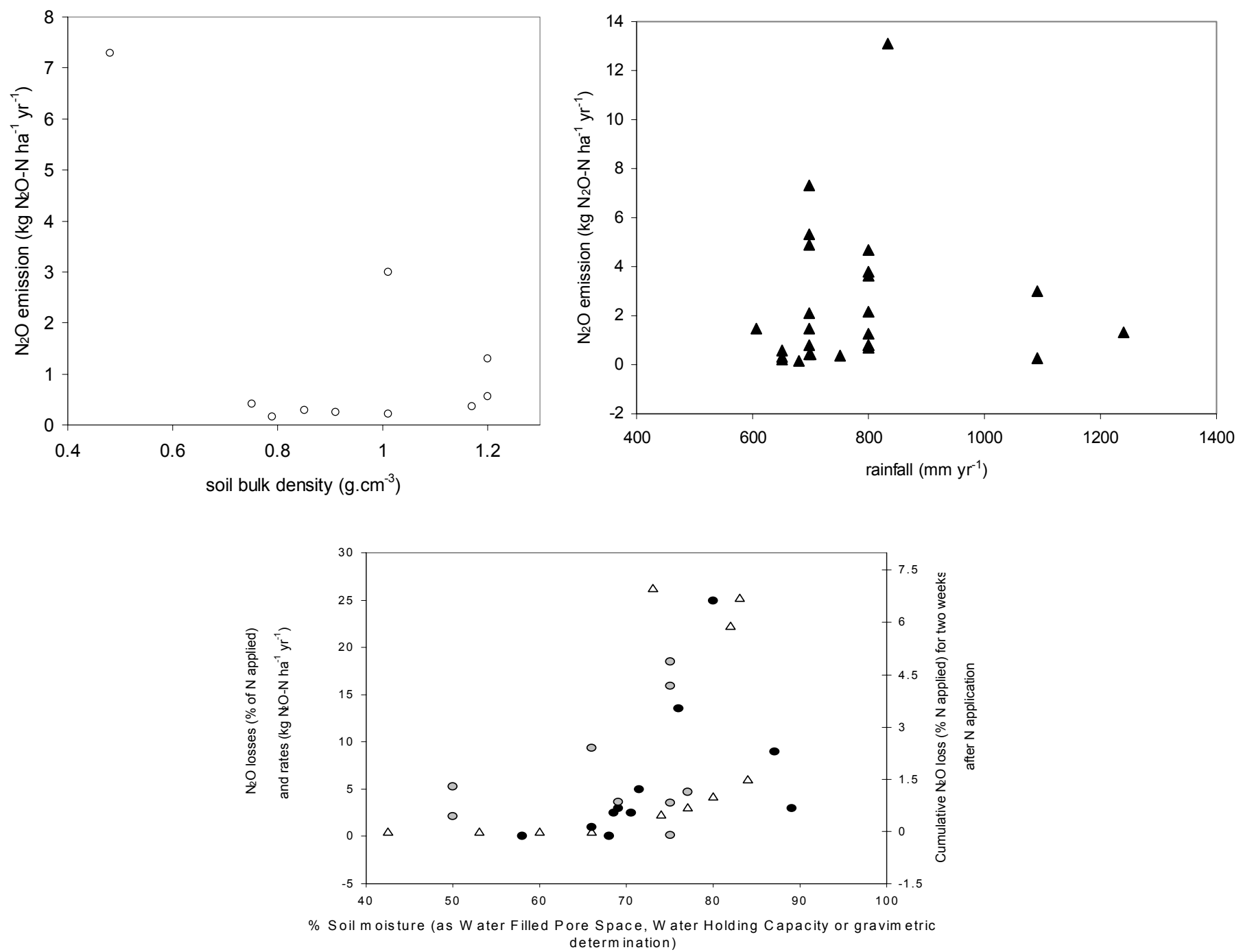

Fig. 2. Relationships between annual nitrous oxide emissions and soil bulk density, annual precipitation and soil moisture. (\) All data (13 references from Appendix 1 and Brumme et al., 1999). (O) Data points from Brumme et al., 1999. (•) Data set for sugar cane, banana and pasture in the tropics of Costa Rica. The data were redrawn from Veldkamp et al. (1998). (4) Data points from managed grassland in W.

Europe (Dobbie et al., 1999). Grey circles represent the data from agricultural soils in Europe (see studies in Appendix 1). The scale for the $\mathrm{N}_{2} \mathrm{O}$ data from the tropical soils and from the agricultural data is on the left side of the graph, from the grassland data on the right side of the graph.

(1999) and those from the 13 references considered in Appendix 1 show that no strong relationship exists between $\mathrm{N}_{2} \mathrm{O}$ emissions and rainfall (Fig. 2).

High $\mathrm{N}_{2} \mathrm{O}$ emissions measured by Brumme et al. (1999) took place when the soil water content was near field capacity $(\sim 1 \mathrm{kPa})$ and lasted until the soil water suction reached $2 \mathrm{kPa}$. Once this threshold was reached, $\mathrm{N}_{2} \mathrm{O}$ emissions decreased. In the study of Skiba et al. (1996) daily and even seasonal changes in moisture were not very well correlated with $\mathrm{N}_{2} \mathrm{O}$ fluxes. However, they observed a strong correlation between annual precipitation and annual $\mathrm{N}_{2} \mathrm{O}$ fluxes. Their data for a coniferous forest in central Scotland gives some clues about the relative importance of temperature and soil moisture. They observed, for the same soil, that wetter soil at lower temperatures had higher fluxes than drier soil at higher temperatures $\left(0.47 \mathrm{~kg} \mathrm{~N} \mathrm{ha}^{-1}\right.$ with a mean soil moisture content of $34 \%$ of soil dry weight and average soil temperature of $10^{\circ} \mathrm{C}$ for 1993 ; and $0.3 \mathrm{~kg} \mathrm{~N}$ $\mathrm{ha}^{-1}$ with a mean soil moisture content of $25 \%$ of soil dry weight and average soil temperature of $12^{\circ} \mathrm{C}$ for 1994). Mogge et al. (1998), in their study of two forest sites in Höglwald, Germany, show that an increase in soil moisture, due to precipitation, contributed to the high $\mathrm{N}_{2} \mathrm{O}$ emissions observed at both sites (precipitation recorded from July to September and in December). The same positive correlation was reported in another of their studies (Mogge et al., 1999). The literature also suggests that a threshold for soil gravimetric water content of about $60-70 \%$ exists above 
which significant $\mathrm{N}_{2} \mathrm{O}$ emission can be obtained. In temperate climates (Dobbie et al., 1999) as well as in the tropics (Veldkamp et al., 1998), maximum $\mathrm{N}_{2} \mathrm{O}$ emissions have been found to occur at a water filled pore space (WFPS) of $75-85 \%$ (weight/weight, Fig.2). This has also been found across Europe for different ecosystems (Mogge et al., 1998; Ruser et al., 1998). As well as regulating the emission rate, water filled pore space regulates the proportion of $\mathrm{N}_{2} \mathrm{O}$ emission from nitrification and denitrification due to its effect on $\mathrm{O}_{2}$ diffusion. In soils with good oxygen supply, emission of $\mathrm{NO}$ should dominate while $\mathrm{N}_{2} \mathrm{O}$ may be the main product in moderately aerated soils. Nitrous oxide and NO losses are both high in poorly aerated soils and only in very poorly aerated soils (waterlogged soils with Eh close to $0 \mathrm{~V}$ ) does $\mathrm{N}_{2}$ emission dominate.

Soil moisture is clearly influencing $\mathrm{N}_{2} \mathrm{O}$ emissions whereas rainfall shows no clear relationship with fluxes. This may be a result of the different response soils have to rainfall according to their nature. For instance, where soils contain higher percentages of clay, diffusion of the water through the soil will be slower and high rainfall will not necessarily result in higher soil moisture content. Also, part of the rainfall will be accounted for as runoff water.

\section{N INPUT, N OUTPUT, N FERTILISATION, N SATURATION}

Nitrogen availability is another control for nitrification and denitrification, but different forms of inorganic $\mathrm{N}$ will have different effects: $\mathrm{NH}_{4}^{+}$availability will influence nitrification, and denitrification will be affected by $\mathrm{NO}_{3}$ availability (Table 1). However, the two processes are closely linked, since $\mathrm{NO}_{3}{ }^{-}$ions are produced by nitrification of $\mathrm{NH}_{4}^{+}$. It is still unclear what the minimum concentrations for $\mathrm{NO}_{3}^{-}$and $\mathrm{NH}_{4}^{+}$are below which denitrification or nitrification will not occur.

Data on forested ecosystems in Europe (NITREX, Matzner, 1989) showed that nitrogen deposition affects the excess of nitrogen in the soil solution. Brumme et al. (1999) did not find any effect of $\mathrm{N}$ deposition on $\mathrm{N}_{2} \mathrm{O}$ emissions from sites with background emissions, presumably where $\mathrm{N}$ deposition did not result in excess mineral $\mathrm{N}$ in the soil. However, they observed high $\mathrm{N}_{2} \mathrm{O}$ emissions from the two sites where 'seasonal' emissions were observed. It is unclear why such high emissions were found at the Solling beech stand and in the case of the drained alder forest in Bornhöved it could be explained by the fact that alders are $\mathrm{N}$-fixing species which can exude nitrate into the soil from their nodules and also produce leaf litter with a high $\mathrm{N}$ content. The Intergovernmental Panel on Climate Change (1997) estimated that $1 \%$ of the $\mathrm{N}$ supplied by atmospheric deposition to natural soils is emitted as $\mathrm{N}_{2} \mathrm{O}$. This is a simple estimate (or 'default value') based on readily available input data. In Fig. 3, the data points significantly above the 1\% IPCC default line are from sites which had received continuous elevated $\mathrm{N}$ deposition rates for many years. Many of the values below this line but receiving high $\mathrm{N}$ deposition are from field experiments where elevated $\mathrm{N}$ deposition was simulated for a relatively short time. In the sites studied by Brumme et al. (1999), the minimum $\mathrm{N}$ deposition is about $20 \mathrm{~kg} \mathrm{~N} \mathrm{ha}^{-1} \mathrm{yr}^{-1}$ (Table 2). Applying fertiliser only seemed to generate pulses of $\mathrm{N}_{2} \mathrm{O}$ emission but showed no long-term effect. Results for agricultural sites from Skiba et al. (1996) showed a positive response of $\mathrm{N}_{2} \mathrm{O}$ emissions a few weeks after fertilisation. This has also been observed by Mogge et al. (1999). Moreover, the timing of fertiliser application appears to be an important factor affecting annual fluxes, with higher annual $\mathrm{N}_{2} \mathrm{O}$ fluxes if fertiliser is applied during warmer months. Major increases in $\mathrm{N}_{2} \mathrm{O}$ flux can occur shortly after fertilisation, with near background emissions restored within several weeks after application (Skiba and Smith, 2000).

Together, the $\mathrm{N}$-deposition and $\mathrm{N}$-fertilisation data suggest that the ' $\mathrm{N}$ status' of the sites, i.e. the availability of mineral $\mathrm{N}$ substrate for nitrification and denitrification (applied, or derived from organic $\mathrm{N}$ applied), is probably a secondary control for $\mathrm{N}_{2} \mathrm{O}$ emissions after moisture and temperature. However, $\mathrm{N}_{2} \mathrm{O}$ emission will only occur if a minimum level of $\mathrm{N}$ substrate is present in the sites. It may also be that $\mathrm{N}_{2} \mathrm{O}$ losses will increase linearly with $\mathrm{N}$ input once the system has reached optimum levels of the other factors controlling $\mathrm{N}_{2} \mathrm{O}$ emission.

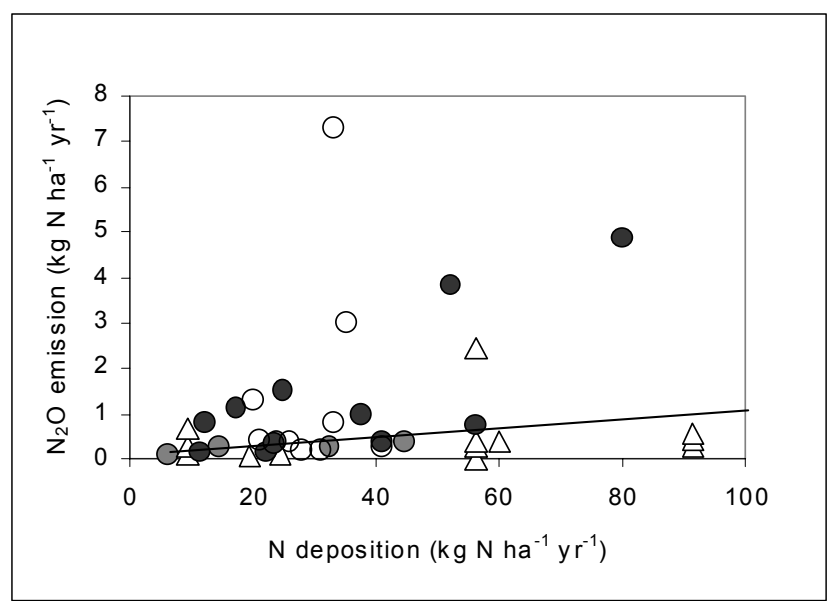

Fig. 3. $N$ deposition induced emissions from forest and moorland soils. In upland areas (grey circles), large-scale acid mist experiments $(\Delta)$, downwind of point sources: poultry and pig farms $(\bullet)$, and German forests (O), IPCC emission factor $1 \%$ (solid line). 


\section{CARBON SOURCE, LITTER QUALITY, CROP TYPE}

Another factor to be considered when looking at $\mathrm{N}_{2} \mathrm{O}$ emissions is the carbon source. This is an important control for denitrification. In their study, Brumme et al. (1999) looked at the effect on annual $\mathrm{N}_{2} \mathrm{O}$ emissions of the mass of the organic horizon in the soils studied (Fig. 4). Unfortunately there are not enough data to draw definite conclusions. Figure 4 suggests that an increase in the mass of the upper organic horizon provides an additional carbon source for nitrification/denitrification for which it might be possible to determine a threshold with more data. Nitrous oxide fluxes may be higher for organic upper horizon $>100 \mathrm{tha}^{-1}$. However, as for nitrogen inputs, this only seems to have a secondary effect on $\mathrm{N}_{2} \mathrm{O}$ emissions.

Different crop types appear to emit different amounts of $\mathrm{N}_{2} \mathrm{O}$. This has been shown by Skiba et al. (1996) in their study of a range of agricultural and semi-natural soils in south and central Scotland. For instance, a potato crop emitted more $\mathrm{N}_{2} \mathrm{O}$ than cereals. An explanation for this was the contribution of more labile crop residues following harvest, and root exudation during tuber development. Dobbie et al. (1999) obtained higher emission factors from potato and brassica crops (1.8-7\% of $\mathrm{N}$ applied) than for wheat and barley $(0.2-0.7 \%$ of $\mathrm{N}$ applied). This was also found by Henault et al. (1998) for wheat compared to oil seed rape $(0.42$ compared to $0.55 \%)$. Similar observations have been made by Brumme et al. (1999) regarding the litter quality in forested ecosystems. In an experiment where litter fall between beech and spruce stands was exchanged (Solling, Germany), $\mathrm{N}_{2} \mathrm{O}$ emissions increased in the spruce stand after application of beech litter and decreased in the beech stand after spruce litter had been applied. However, the change in $\mathrm{N}_{2} \mathrm{O}$ flux between controls and treated plots was much less than the actual differences between control

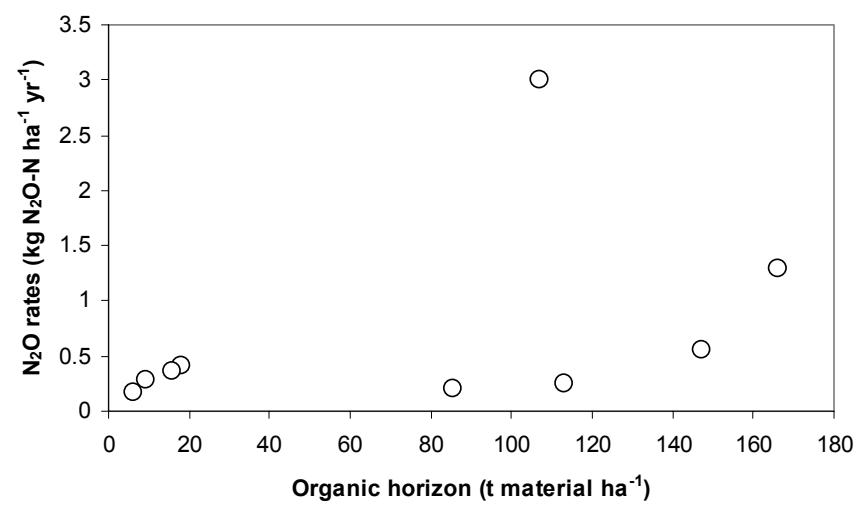

Fig. 4. Relationship between annual nitrous oxide rates and the total mass of material in the organic upper horizon. Data from Brumme et al., 1999 stands, suggesting either that a longer time is needed to obtain a flux response or that other factors are important.

\section{TEMPERATURE}

Both nitrification and denitrification rates are controlled by soil temperature. The rapid increase in process rates with increasing temperature suggests that the response to temperature is primarily a biochemical response rather than a population one. Temperature is also a daily control and a fast response parameter. Seasonal and diurnal changes in temperature have been shown to be correlated, directly and linearly, with $\mathrm{N}_{2} \mathrm{O}$ emission for many soils in temperate climates (Skiba et al., 1998; Skiba and Smith, 2000). But this is only true when other important factors such as WFPS or mineral $\mathrm{N}$ are not limiting. This was shown by Dobbie et al. (1999) in their study of intensively managed agricultural fields, with $\mathrm{Q}_{10}$ values of up to 8. In their study of 11 forest soils in Germany, Brumme et al. (1999) observed an increase of the $\mathrm{N}_{2} \mathrm{O}$ emission from $6 \mu \mathrm{g} \mathrm{N} \mathrm{N}_{2} \mathrm{O}-\mathrm{N} \mathrm{m}^{-2} \mathrm{~h}^{-1}$ up to a more or less constant level of about $90 \mu \mathrm{g} \mathrm{N}_{2} \mathrm{O}-\mathrm{N} \mathrm{m}^{-2} \mathrm{~h}^{-1}$ when soil temperature exceeded $10^{\circ} \mathrm{C}$. Their data also indicated that during the period of high emissions $\mathrm{N}_{2} \mathrm{O}$ fluxes followed changes in temperature. The $\mathrm{Q}_{10}$ values obtained for this same study were as high as 14 . Such an extremely high $\mathrm{Q}_{10}$ is partially explained by temperature-induced positive feedback. For instance, a rise in temperature will have an effect on soil respiration and anaerobicity thus influencing nitrification and denitrification rates (Smith, 1997). In addition, the data obtained by Brumme et al. (1999) show that $\mathrm{N}_{2} \mathrm{O}$ fluxes are related to the air temperature (Fig. 5) with small fluxes at temperatures below $8^{\circ} \mathrm{C}$ and larger fluxes more likely to happen at higher temperature, but depending on other factors. $\mathrm{N}_{2} \mathrm{O}$ fluxes will also be related

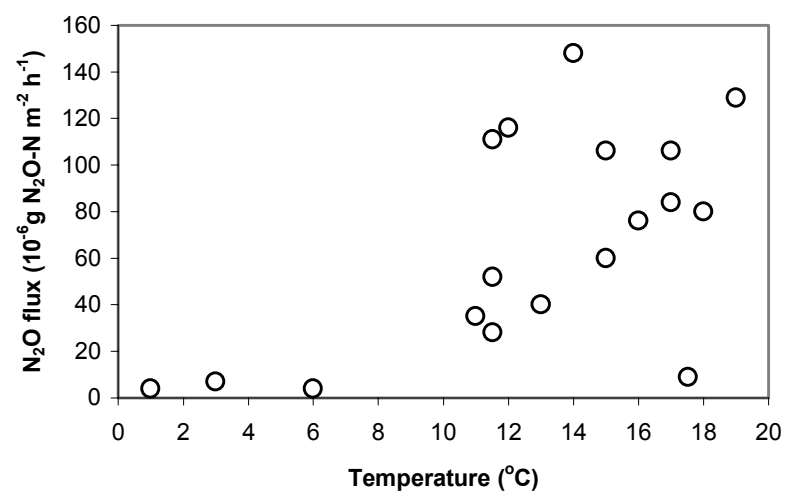

Fig. 5. Relationship between annual air temperature and $\mathrm{N}_{2} \mathrm{O}$ flux. Data redrawn from Brumme et al.,1999. 
to the soil temperature since the soil temperature is related to air temperature but is lagged with time and damped with depth. For the Brumme et al. (1999) study, only air temperature was available. This is often the case since air temperature are readily available.

Studies such as Mogge et al. (1999), Flessa et al. (1995) or Papen and Butterbach-Bahl (1999) showed peaks of $\mathrm{N}_{2} \mathrm{O}$ emissions during freeze-thaw periods. Brumme et al. (1999) also showed that freeze-thaw influences $\mathrm{N}_{2} \mathrm{O}$ fluxes but only at one of the sites studied. The effect of temperature on $\mathrm{N}_{2} \mathrm{O}$ emission can be counteracted by its stimulating effect on plant growth, thus enhancing the competition for $\mathrm{NO}_{3}^{-}$and $\mathrm{NH}_{4}^{+}$.

More generally, denitrifying organisms can adapt to local temperatures (and possibly other local conditions): Powlson et al. (1988) showed that denitrifiers from England and Australia denitrified at the same rate when at local optimum temperatures of 10 and $20^{\circ} \mathrm{C}$, respectively.

\section{NET EFFECT}

The response of $\mathrm{N}_{2} \mathrm{O}$ emissions to factors such as soil moisture, rainfall, $\mathrm{N}$ deposition, $\mathrm{N}$ fertilisation, carbon source, crop type or temperature is very variable and depends on the interactions of these factors with each other. A better way to estimate and predict $\mathrm{N}_{2} \mathrm{O}$ emissions in different European ecosystems might be to use emission functions developed from empirical models that use broad controlling factors such as land use and climate. Figure 1 shows a clear difference between land uses such as forests or agriculture. An interactive multilayered model in which the controls would be activated by thresholds is shown in Fig. 6. These operate over different time scales. For instance, hydrology and mean annual soil temperature are long-term site attributes that are regulated by the regional climate, topography, etc. These establish the overall potential of the site for $\mathrm{N}_{2} \mathrm{O}$ fluxes.

Threshold values of dissolved inorganic N and DOC and WFPS are then required for actual denitrification or nitrification. Variation in these over a seasonal to weekly time scale will affect the amount of $\mathrm{N}_{2} \mathrm{O}$ released over a given season. Changes in these values may not immediately affect $\mathrm{N}_{2} \mathrm{O}$ fluxes since they may operate by changing competitive relationships among different populations of micro-organisms. Shifts in these relationships may take place after a time lag. A change in soil temperature, however, may immediately affect $\mathrm{N}_{2} \mathrm{O}$ fluxes as it operates on the biochemical scale. If any of the controlling factors is below the threshold, $\mathrm{N}_{2} \mathrm{O}$ flux will not occur. This concept is similar to that developed by Skiba and Smith (2000) for agricultural systems, and by Ulrich (1994) and Brumme et al. (1999) for forest ecosystems.

\section{Conclusion}

Nitrous oxide emissions vary widely. Results from European studies show that $\mathrm{N}_{2} \mathrm{O}$ emissions are not strongly correlated to precipitation whereas soil moisture levels are a major control, interacting with secondary controls such as $\mathrm{N}$ deposition, fertiliser use, carbon source and soil temperature. Nitrous oxide emissions will occur when these controlling factors are not limiting, i.e. above a certain threshold. Furthermore, the complexity of these interactions makes prediction of $\mathrm{N}_{2} \mathrm{O}$ emissions and simple relationships between fluxes and factors difficult to obtain. In order to derive more reliable estimates of $\mathrm{N}_{2} \mathrm{O}$ emission, interactive

Climate, topography

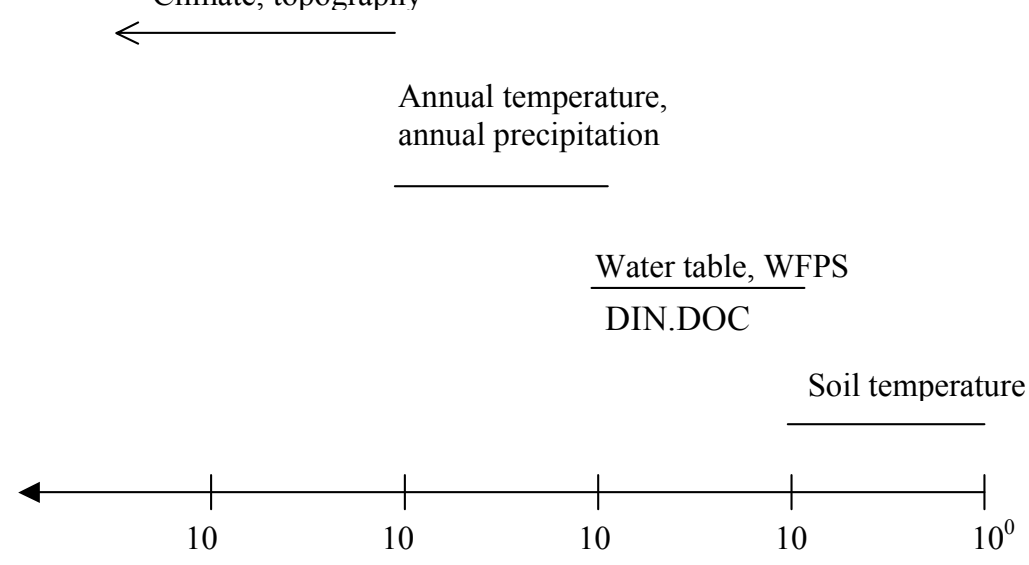

Time (log) days

Fig. 6. Major controls on denitrification and nitrification, and approximate time scale of change of importance to $\mathrm{N}_{2} \mathrm{O}$ fluxes 
multilayered models are needed which describe $\mathrm{N}$ dynamics and $\mathrm{N}_{2} \mathrm{O}$ emissions as function of climate and land use. While these models are lacking, the use of emission factors such as those proposed by the IPCC (1997) or Brown et al. (2001) offer the simplest way to estimate $\mathrm{N}_{2} \mathrm{O}$ emissions. However, as Brown et al. (2001) show, the IPCC default values are gross approximations. Those wanting more precise estimates must resort to site-specific measurements or dynamic models such as DNDC (Li et al., 1992, 1996) or SUNDIAL (Smith et al., 1996).

\section{Acknowledgements}

This research is supported by the European Commission (Project EVK1-1999-00011), and the results are derived from collaborations between all project partners, who are listed on the project website: http://www.reading.ac.uk/ INCA. IACR-Rothamsted receives grant-aided support from the UK Biotechnology and Biological Sciences Research Council.

\section{References}

Ambus, P. and Christensen, S., 1995. Spatial and seasonal Nitrous Oxide and Methane fluxes in Danish forest, grassland, and agroecosystems. J. Environ. Qual., 24, 993-1001.

Bange, H.W., 2000. It's not a gas. Nature, 408, 301-302.

Black, A.S., Purnomo, E., Young, S.R. and Conyers, M., 1998. N mineralisation and nitrification in crop and pasture soils. $9^{\text {th }}$ Australian Agronomy Conference, Charles Stuart University Convention Centre.

Bouwman, A.F., 1990. Soils and the greenhouse effect, Springer, New York, 103-148.

Bouwman, A.F., 1998. Nitrogen oxides and tropical agriculture. Nature, 392, 866-867.

Bremner, J.M. and Blackmer, A.M., 1981. Terrestrial nitrification as a source of atmospheric nitrous oxide. In: Denitrification, nitrification, and atmospheric nitrous oxide. C.C. Delwiche, (Ed.), Wiley, New York, 151-170.

Brown, L., Armstrong Brown, S., Jarvis, S.C., Syed, B., Goulding, K.W.T., Phillips, V.R., Sneath, R.W. and Pain, B.F., 2001. An inventory of nitrous oxide emissions from agriculture in the UK using the IPCC methodology: emission estimate, uncertainty and sensitivity analysis. Atmos. Environ., 35, 1439-1449.

Brumme, R., Borken, W. and Finke, S., 1999. Hierarchical control on nitrous oxide emission in forest ecosystems. Global Biogeochem. Cycle, 13, 1137-1148.

Burford, J.R. and Bremner, J.M., 1975. Relationships between the denitrification capacities of soils and total water-soluble and readily decomposable soil organic matter. Soil Biol. Biochem., 7, 389-394.

Burt, T.P., Matchett, L.S., Goulding, K.W.T., Webster, C.P. and Haycock, N.E., 1999. Denitrification in riparian buffer zones: the role of floodplain hydrology. Hydrol. Process., 13, 14511463.

Davidson, E.A., 1991. Fluxes of nitrous oxide and nitric oxide from terrestrial ecosystems. In: Microbial Production and Consumption of Greenhouse gases: Methane, Nitrogen oxides and Halo-Methanes, J.E. Rogers and W.B. Whitman, (Eds.), 219-235. Amer. Soc. Microbiol., Washington, DC.
Dobbie, K.E., McTaggart, I.P. and Smith, K.A., 1999. Nitrous oxide emissions from intensive agricultural systems: Variations between crops and seasons, key driving variables, and mean emission factors. J. Geophys. Res.: Atmos, 104, 26,891-26,899.

Flessa, H., Dorsch, P. and Beese, F., 1995. Seasonal variation of $\mathrm{N}_{2} \mathrm{O}$ and $\mathrm{CH}_{4}$ fluxes in differently managed arable soils in southern Germany. J. Geophys. Res., 100, 23,115-23,124.

Groffman, P.M., 1991. Ecology of nitrification and denitrification in soil evaluated at scales relevant to atmospheric chemistry. In: Microbial Production and Consumption of Greenhouse Gases: Methane, Nitrogen Oxides and Halomethanes. W.B. Whitman and J. Rogers, (Eds.), Amer. Soc. Microbiol., Washington, DC, 201-217.

Henault, C., Devis, X., Page, S., Justes, E., Reau, R. and Germon, J.C., 1998. Nitrous oxide emissions under different soil and land management conditions. Biol. Fertil. Soils, 26, 199-207.

Hutchinson, G.L. and Mosier, A.R., 1981. Improved soil cover method for field measurements of nitrous oxide fluxes. Soil Sci. Soc. Amer. J., 45, 311-316.

IPCC (Intergovernmental Panel on Climate Change), 1997. Greenhouse Gas emissions from agricultural soils. In: Greenhouse Gas Inventory Reference Manual, Houghton, J.T., et al. (Eds.). Revised 1996 IPCC Guidelines for National Greenhouse Gas Inventories. IPCC/OECD/IES. UK Meteorological Office, Bracknell, UK.

Kasica, A.F., 1997. Something to grow on. A.F. Kasica and G.L. Good, (Eds.), World Wide Web designed by R.D. Scott.

Lashof, D.A. and Ahuja, D.R., 1990. Relative contribution of greenhouse gas emissions to global warming. Nature, 344, 529 531.

Li, C., Frolking, S. and Frolking, T.A., 1992. A model of nitrous oxide evolution from soil driven by rainfall events. 1. Model structure and sensitivity. J. Geophys. Res., 97, 9759-9776.

Li, C., Narayanan, V. and Harriss, R., 1996. Model estimates of nitrous oxide emissions from agricultural lands in the United States. Global Biogeochem. Cycle, 10, 297-306.

Martikainen, P.J., Nykanen, H., Silvola, J., Alm, J., Lang, K., Smolander, A. and Ferm, A., 1994. Nitrous oxide emissions from some natural environments in Finland. In: Proceedings of the $6^{\text {th }}$ International Workshop on Nitrous Oxide Emissions, 553560.

Matzner, E., 1989. Acid precipitation: Case study Solling. In: Acid precipitation, D.C. Adriano and M. Havas, (Eds.), 95-115, Springer, New York.

Mogge, B., Kaiser, E.A. and Munch, J.C., 1998. Nitrous oxide emissions and denitrification $\mathrm{N}$-losses from forest soils in the Bornhöved Lake region (Northern Germany).Soil Biol. Biochem., 30, 703-710.

Mogge, B., Kaiser, E.A. and Munch, J.C., 1999. Nitrous oxide emissions and denitrification $\mathrm{N}$-losses from agricultural soils in the Bornhoved Lake region: influence of organic fertilisers and land-use. Soil Biol. Biochem., 31, 1245-1252.

Nieminen, M., 1998. Changes in nitrogen cycling following the clear-cutting of drained peatland forests in Southern Finland. Boreal Environ. Res., 3, 9-21.

Papen, H. and Butterbach-bahl, K., 1999. A 3-year continuous record of nitrogen trace gas fluxes from untreated and limed soil of a N-saturated spruce and beech forest ecosystem in Germany: $\mathrm{N}_{2} \mathrm{O}$ emissions. J. Geophys. Res., 104, 18,48718,503.

Poth, M. and Focht, D.D., 1985. ${ }^{15} \mathrm{~N}$ kinetic analysis of $\mathrm{N}_{2} \mathrm{O}$ production by Nitrosomonas Europeae: An examination of nitrifier denitrification. Appl. Environ. Microbiol., 49, 11341141.

Powlson, D.S., Saffigna, P.G. and Kragt-Cottaar, M., 1988. Denitrification at sub-optimal temperatures in soils from different climatic zones. Soil Biol. Biochem., 20, 719-723. 
Regina, K., Nykanen, H., Silvola, J. and Martikainen, P.J., 1996. Fluxes of nitrous oxide from boreal peatlands as affected by peatland type, water table level and nitrification capacity. Biogeochemistry, 35, 401-418.

Robertson, L.A. and Kuenen, J.G., 1991. Physiology of nitrifying and denitrifying bacteria. In: Microbial Production and Consumption of Greenhouse Gases: Methane, Nitrogen Oxides and Halomethanes, J.E. Rogers and W.B. Whitman, (Eds.), Amer. Soc. Microbiol., Washington, DC, 189-199.

Ruser, R., Flessa, H., Schilling, R., Steidl, H. and Beese, F., 1998. Soil compaction and fertilisation effects on nitrous oxide and methane fluxes in potato fields. Soil Sci. Soc. Amer. J., 62, 15871595.

Skiba, U. and Smith, K.A., 2000. The control of nitrous oxide emissions from agricultural and natural soils. ChemosphereGlob. Change Sci. , 2, 379-386.

Skiba, U.M., McTaggart, I.P., Smith, K.A., Hargreaves, K.J. and Fowler, D., 1996. Estimates of nitrous oxide emissions from soil in the UK. Energ Conv. and Manage., 37, 1303-1308.

Skiba, U., Sheppard, L., Pitcairn, C.E.R., Leith, I., Crossley, A., van Dijk, S., Kennedy, V.H. and Fowler, D., 1998. Soil nitrous oxide and nitric oxide emissions as indicators of elevated atmospheric $\mathrm{N}$ deposition rates in semi-natural ecosystems. Environ. Poll., 102, 457-461.

Smith, K.A., 1997. The potential for feedback effects induced by global warming on emissions of nitrous oxide by soils. Glob. Change Biol., 3, 327-338.

Smith, J.U., Bradbury, N.J. and Addiscott, T.M., 1996. SUNDIAL: A PC-based system for simulating nitrogen dynamics in arable land. Agro. J., 88, 38-43.
Smith, K.A., Clayton, H., Arah, J.R.M., Christensen, S., Ambus, P., Fowler, D., Hargreaves, K.J., Skiba, U., Harris, G.W., Wienhold, F.G., Klemedtsson, L. and Galle, B., 1994. Micrometeorological and chamber methods for measurement of nitrous oxide fluxes between soils and the atmosphere: overview and conclusions. J. Geophys. Res., 99, 16541-16548.

Ulrich, B., 1994. Process hierarchy in forest ecosystems: An integrative ecosystem theory. In: Effects of Acid Rain on Forest Processes, D.L. Godbold and A. Hüttermann, (Eds.), Wiley, New York, 353-397.

Veldkamp, E., Keller, M. and Nuòez, M., 1998. Effects of pasture management on $\mathrm{N}_{2} \mathrm{O}$ and $\mathrm{NO}$ emissions from soils in the humid tropics of Costa Rica. Global Biogeochem. Cycle, 12, 71-79.

Velthof, G.L., Jarvis, S.C., Stein, A., Allen, A.G. and Oenema, O., 1996. Spatial variability of nitrous oxide fluxes in mown and grazed grasslands on a poorly drained clay soil. Soil Biol. Biochem., 28, 1215-1225.

Webster, E.A. and Hopkins, D.W., 1996. Contributions from different microbial processes to $\mathrm{N}_{2} \mathrm{O}$ emission from soil under different moisture regimes. Biol. Fert. Soil, 22, 331-335.

Wrage, N., Velthof, G.L., van Beusichem, M.L. and Oenema, O., 2001. Role of nitrifier denitrification in the production of nitrous oxide. Soil Biol. Biochem., 33, 1723-1732.

Yamulki, S., Jarvis, S.C. and Owen, P., 1998. Nitrous oxide emissions from excreta applied in a simulated grazing pattern. Soil Biol. Biochem., 30, Issue 4, 491-500. 


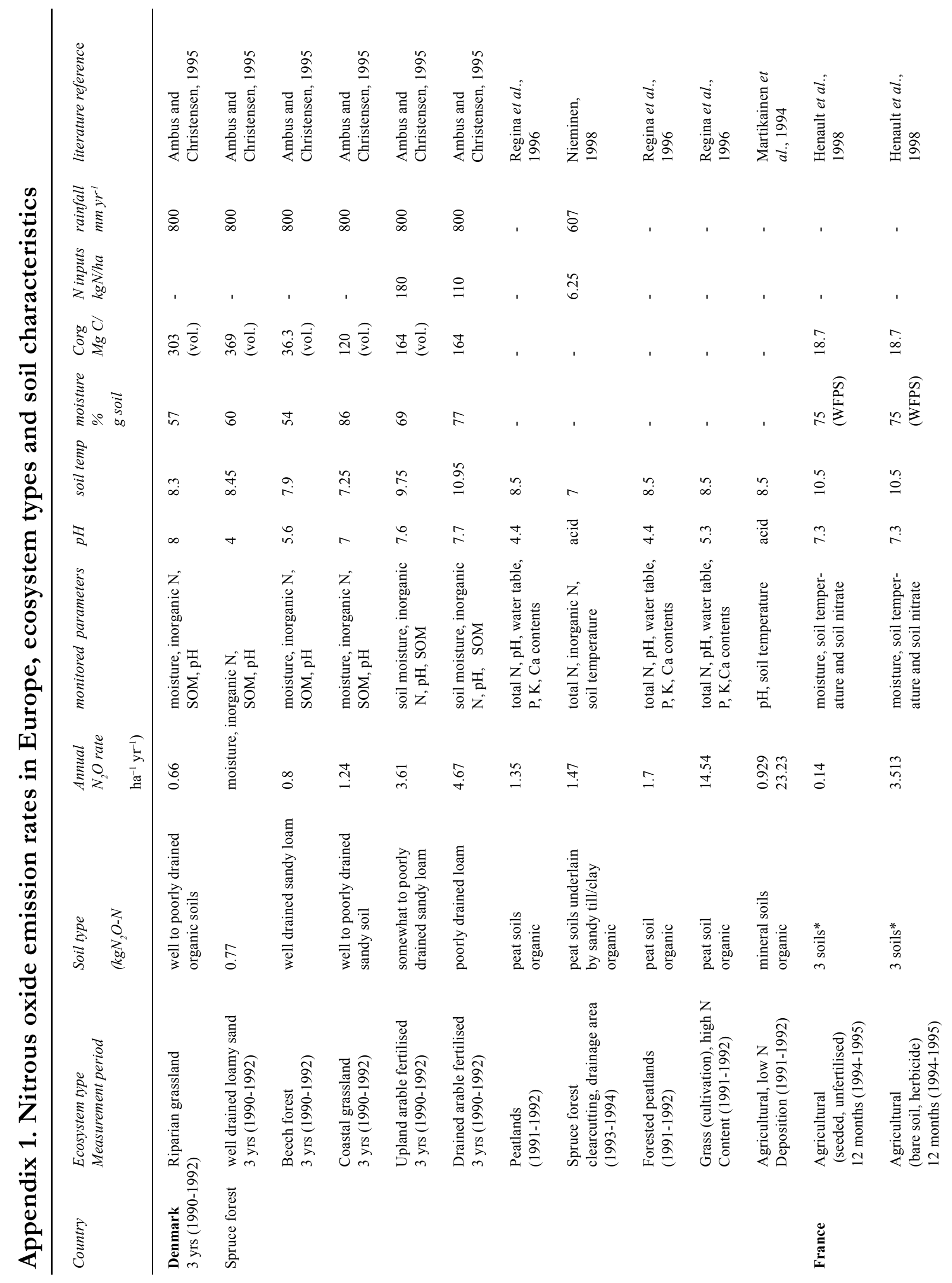




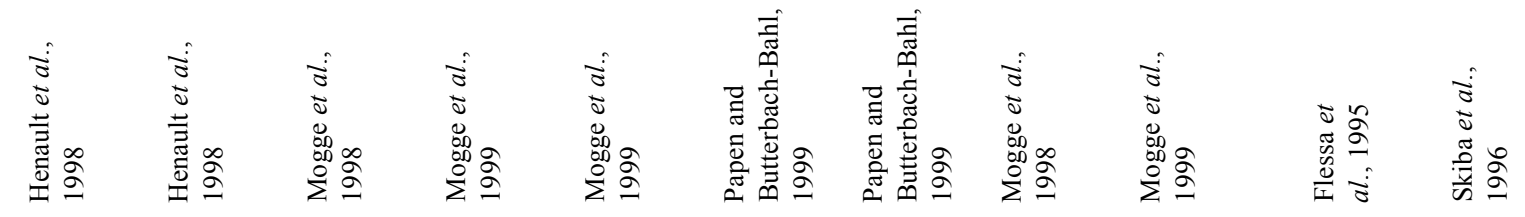

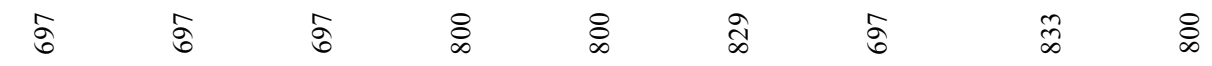

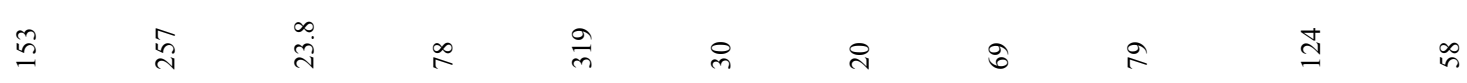

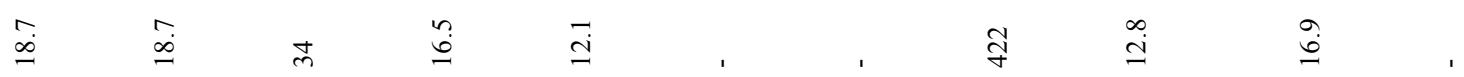

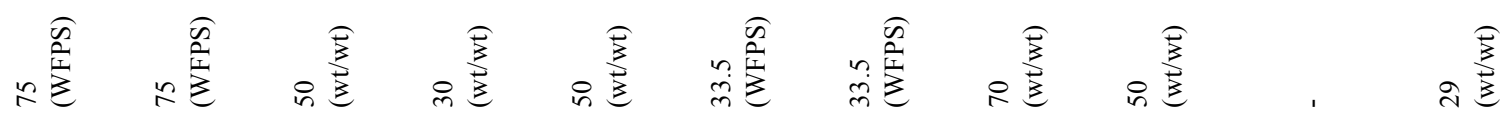

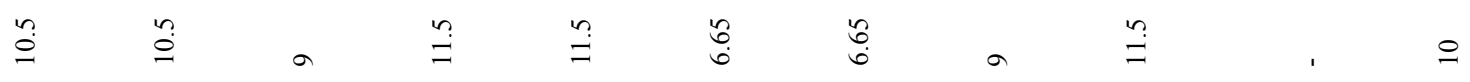

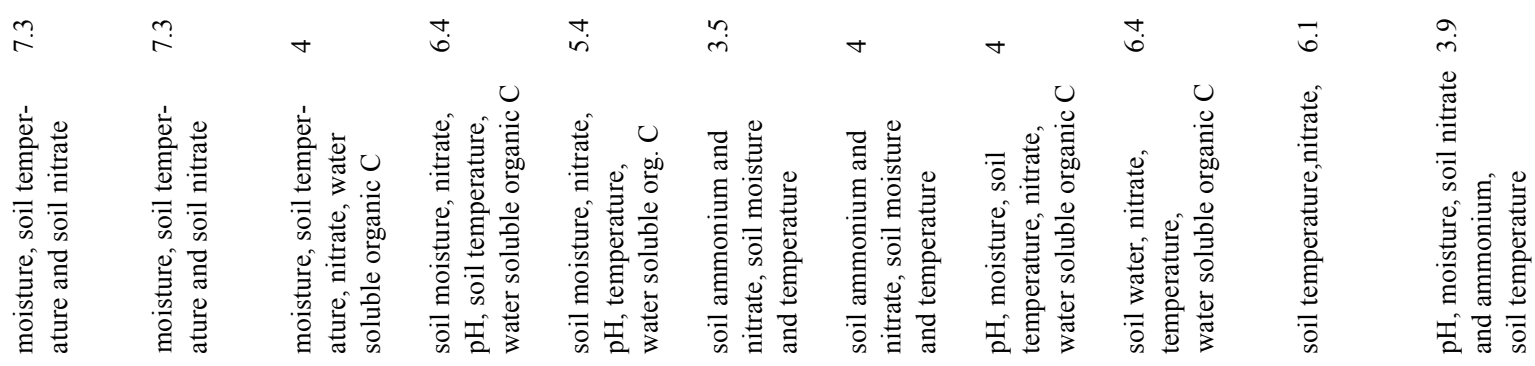

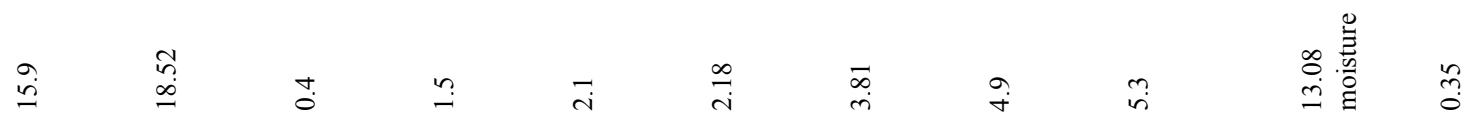

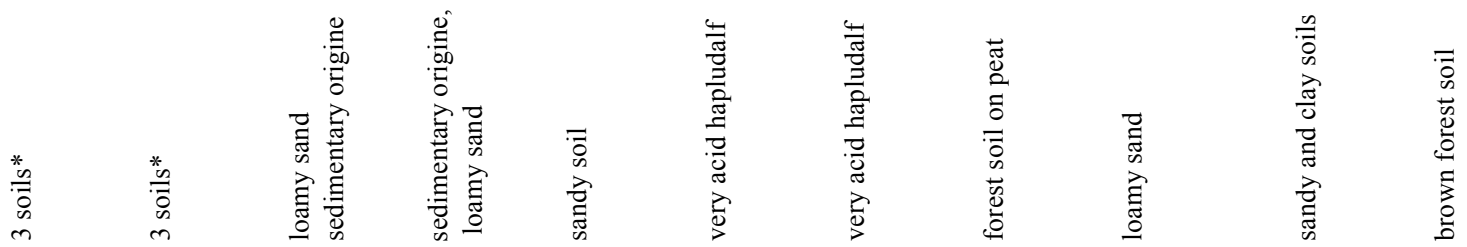

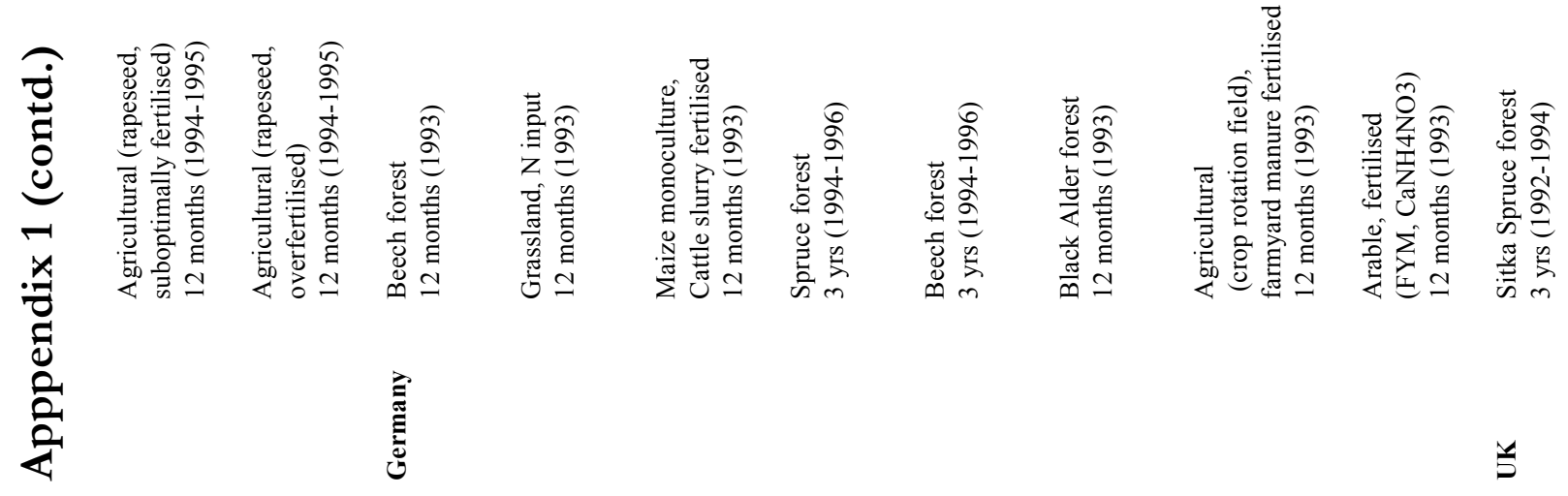




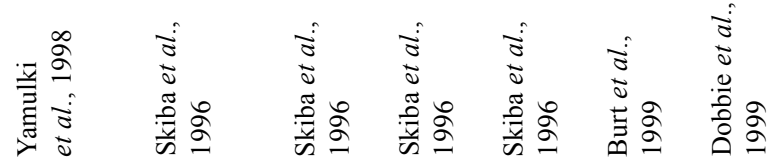

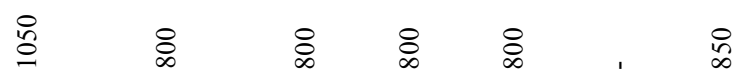

요, 8

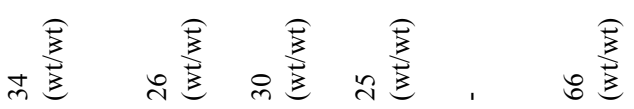

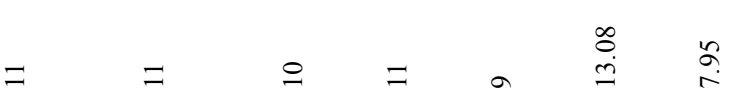

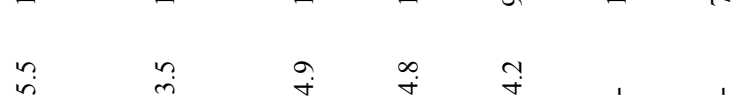

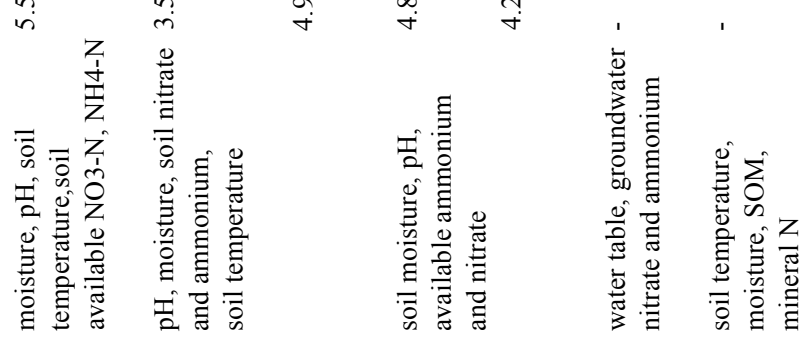

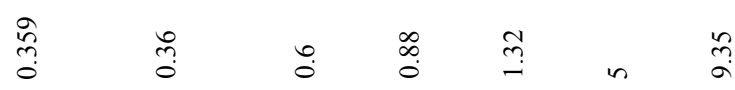

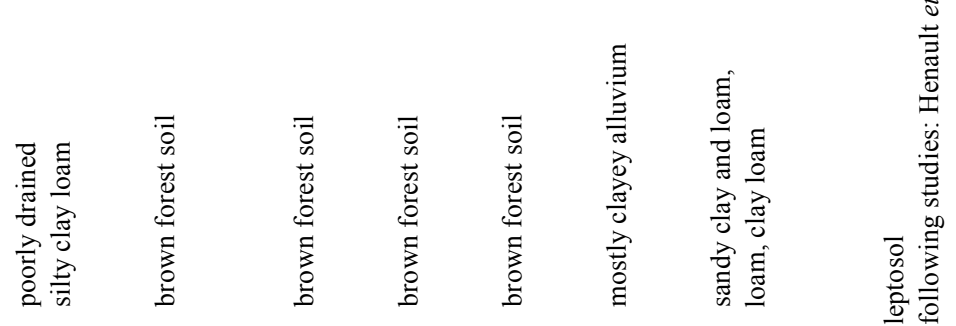

$\stackrel{n}{2}$

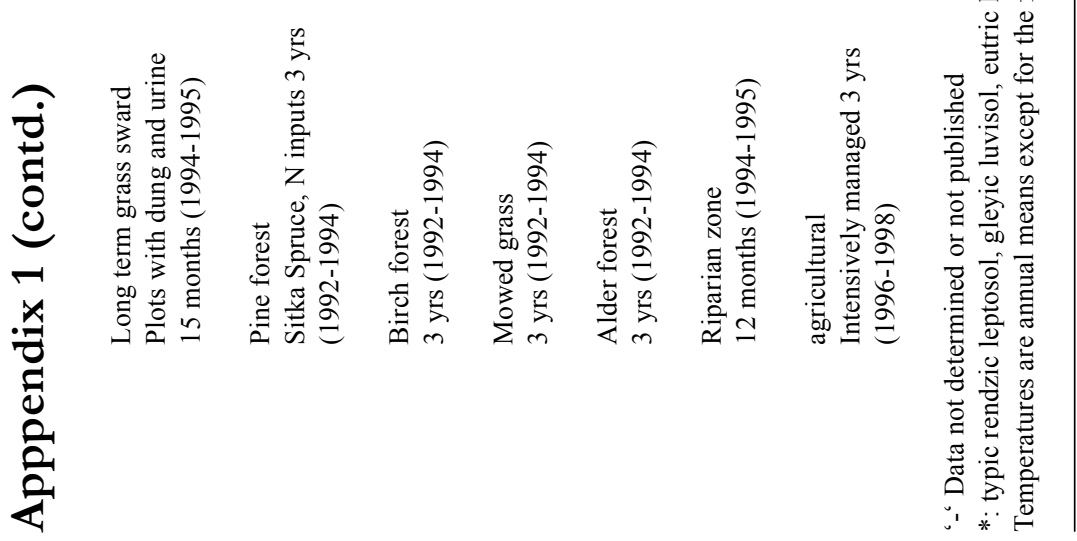


